\title{
Upaya Meningkatkan Hasil Belajar Passing Bawah Bola Voli Melalui Gaya Mengajar Inklusi Pada Siswa Kelas XI SMK Swasta Yapim Biru-Biru Tahun Ajaran 2020/2021
}

\author{
Gunanta Tarigan', Fajar Mugo Raharjo² \\ 1,2 Sekolah Tinggi Olahraga dan Kesehatan Bina Guna, Indonesia \\ Email : gunantatrgn@gmail.com
}

\begin{abstract}
ABSTRAK
Penelitian ini bertujuan untuk mengetahui peningkatan hasil belajar passing bawah bola voli dalam permainan bola voli pada siswa SMKS Yapim Biru-biru Tahun Ajaran 2020/2021. Metode penelitian yang digunakan adalah Penelitian Tindakan Kelas (Classroom Action Research). Subjek penelitian ini adalah siswa kelas XI SMK Swasta Yapim Biru-Biru tahun ajaran 2020/2021 dengan jumlah siswa 17 orang, yang keseluruhannya 17 orang siswa putra. Berdasarkan observasi kemampuan guru dalam kegiatan pembelajaran passing bawah bola voli melalui gaya mengajar inklusi, pada tahap awal kemampuan guru dalam kegiatan pembelajaran dalam kategori cukup $(76,38)$. Sedangkan kemampuan guru setelah di berikan perlakuan dalam kegiatan pembelajaran meningkat menjadi sangat baik $(90,27)$. Selanjutnya, sesuai hasil observasi partisipasi siswa dalam kegiatan pembelajaran passing bawah bola voli melalui gaya mengjar inklusi, pada tahap awal (setelah di beri perlakuan) keterlibatan siswa dalam kegiatan pembelajaran dalam kategori cukup (75.55). Sedangkan setelah di berikan perlakuan keterlibatan siswa dalam kegiatan pembelajaran meningkat menjadi sangat baik (91.1). Kemudian untuk memperoleh hasil belajar keterampilan passing bawah maka dilakukan tes hasil belajar yang dinilai berdasarkan portofolio yang telah disusun. Dari tes hasil belajar siklus I diperoleh 10 siswa (58,82\%) yang telah mencapai ketuntasan belajar, sedangkan 7 siswa $(41,18 \%)$ tidak mencapai ketuntasan belajar dengan nilai rata-rata klasikal 78,21. Pada tes hasil belajar siklus II, siswa mengalami peningkatan hasil belajar yaitu 15 siswa (88,24 \%) telah mencapai ketuntasan belajar, sedangkan 2 siswa (11,76\%) tidak mencapai ketuntasan belajar dengan rata-rata nilai klasikal 85,40. Berdasarkan hasil tes tersebut terjadi peningkatan jumlah siswa yang telah mencapai ketuntasan belajar dan memenuhi kriteria ketuntasan klasikal yaitu $85 \%$. Berdasarkan hasil analisis data diperoleh kesimpulan bahwa melalui gaya mengajar inklusi dapat meningkatkan hasil belajar passing bawah bola voli pada siswa kelas XI SMK Swasta Yapim Biru-Biru Tahun Ajaran 2020/2021.
\end{abstract}

\section{Kata kunci: passing bawah, gaya mengajar inklusi, bola voli}

\begin{abstract}
This study aims to determine the increase in learning outcomes of volleyball underpass in volleyball games for students of Yapim Biru-Biru SMKS for the Academic Year 2020/2021. The research method used is Classroom Action Research. The subjects of this study were students of class XI Yapim Biru-Biru Vocational High School for the academic year 2020/2021 with 17 students, 17 male students in total. Based on observations of the teacher's ability in volleyball passing learning activities through an inclusive teaching style, at the initial stage the teacher's ability in learning activities was in the sufficient category
\end{abstract}


$(76,38)$. Meanwhile, the teacher's ability after being given treatment in learning activities increased to be very good $(90,27)$. Furthermore, according to the results of observations of student participation in volleyball under-passing learning activities through inclusion teaching style, at the initial stage (after being treated) student involvement in learning activities was in the sufficient category (75.55). Meanwhile, after being given treatment, student involvement in learning activities increased to be very good (91.1). Then to obtain the learning outcomes of underpassing skills, a learning outcome test was carried out which was assessed based on the portfolio that had been compiled. From the test of learning outcomes in cycle I, it was obtained 10 students (58.82\%) who had achieved mastery learning, while 7 students $(41.18 \%)$ did not achieve mastery learning with a classical average score of 78.21. In the second cycle learning outcomes test, students experienced an increase in learning outcomes, namely 15 students (88.24\%) had achieved mastery learning, while 2 students $(11.76 \%)$ did not achieve learning completeness with an average classical score of 85.40. Based on the test results, there was an increase in the number of students who had achieved mastery learning and met the classical completeness criteria, namely $85 \%$. Based on the results of the data analysis, it was concluded that through the inclusion teaching style it could improve the learning outcomes of volleyball under-passing learning in class XI students of Yapim Biru-Biru Vocational High School for the Academic Year of 2020/2021.

\section{Keywords: down passing, inclusive teaching style, volleyball}

\section{PENDAHULUAN}

Pendidikan jasmani, olahraga, dan kesehatan merupakan bagian integral dari pendidikan secara keseluruhan dengan tujuan untuk mengembangkan aspek kebugaran jasmani, keterampilan gerak, keterampilan berfikir kritis. Lebih dari itu keterampilan sosial, penalaran, stabilitas emosi juga dapat dikembangkan melalui PJOK. Tindakan moral, aspek pola hidup sehat, dan pengenalan lingkungan bersih melalui aktivitas jasmani, olahraga, dan kesehatan yang direncanakan secara sistematis dalam rangka mencapai tujuan pendidikan nasional. Pendidikan sebagai suatu proses pembinaan manusia yang berlangsung seumur hidup. Pendidikan jasmani, olahraga, dan kesehatan yang diajarkan di sekolah memiliki peranan sangat penting, yaitu memberikan kesempatan kepada peserta didik untuk terlibat langsung dalam berbagai pengalaman belajar melalui aktivitasyang dilakukan secara sistematis. Pembekalan pengalaman belajar itu diarahkan untuk membina pertumbuhan fisik dan pengembangan psikis yang lebih baik, sekaligus membentuk pola hidup sehat dan bugar sepanjang hayat. Melalui proses pembelajaran yang dilakukan, diharapkan peserta didik dapat terampil dalam berolahraga. SMK Swasta Yapim Biru-Biru merupakan salah satu sekolah yang belum menggunakan kurikulum 2013 secara menyeluruh pada tingkatan kelasnya. Secara umum kegiatan pembelajaran pendidikan jasmani melibatkan2 aktivitas fisik, demikian pula hal nya dalam belajar passing bawah pada permainan bola voli. Passing bawah merupakan salah satu teknik dasar dalam permainan bola voli yang dipelajar siswa dalam mata pelajaran PJOK. Demikian halnya di SMK Swasta Yapim Biru-Biru, passing bawah dalam bola voli merupakan salah satu materi pelajaran yang diberikan guru kepada siswa. Namun dalam pelaksanaannya materi pelajaran passing bawah dalam belum dapat sepenuhnya tersampaikan dengan baik sesuai tuntutan kurikulum yang digunakan sekolah yaitu kurikulum tingkat satuan pendidikan.Terlihat dari penyampaian materi yang diberikan guru belum tersampaikan secara sistematis seperti pada fase menalar dan 
mengkomunikasikan tidak terlaksana dalam pembelajaran serta materi tidak secara utuh diterima siswa mengenai materi passing bawah dikarenakan guru tidak memberikan umpan balik maupun penguatan materi yang diberikan pada pembelajaran sehingga hasil belajar passing bawah kurang maksimal. Hal ini dapat terlihat ketika siswa melakukan passing bawah, Gerakan yang di lakukan masih belum sesuai dengan gerakan sebenarnya yang meliputi pada tahap persiapan,diantara yang salah seperti pandangan tidak melihat ke bola, posisi tangan yang tidak di letakan di tempat yang benar dalam memegang genggaman saat melakukan tehnik tersebut, ketika pelaksanaan perkenaan bola yang tidak tepat, dan pada fase akhir banyak siswa yang terlihat kaku setelah melakukan passing bawah. Guru pendidikan jasmani olahraga dan kesehatan selama ini memberikan materi passing bawah kurang menguasai bahan. Hal ini menyebabkan proses pembelajaran passing bawah menjadi monoton, karena guru lebih terkesan lebih banyak berperan dalam pembelajaran sedangkan siswa lebih banyak mendengarkan dan meniru gerakan yang di perankan guru penjas. situasi seperti ini kurang mendukung atas kemampuan siswa terutama dalam memahami suatu pembelajaran passing bawah pembelajaran dengan metode lama atau ceramah menyebabkan sisiwa tidak dapat mengembangkan kemampuan imajinasinya dan daya fikirnya .

Faktor yang mempengaruhi hasil belajar sisiwa di antaranya adalah motivasi, minat, bakat, semangat, kondisi fisik, sarana atau media pembelajaran guru, metode atau strategi pembelajaran yang di gunakan oleh guru dan lain - lain. Menyadari hal tersebut, perlu adanya suatu pembaharuan dalam pembelajaran untuk memungkinkan siswa dapat mempelajari materi passing bawah bola voli jauh lebih mudah, lebih cepat, lebih bermakna, efektif dan menyenangkan. Salah satu nya ialah dengan memilih gaya mengajar yang tepat. Sebelum menentukan gaya mengajar yang akan di gunakan dalam proses kegiatan belajar mengajar nantinya, seorang guru haruslah terlebih dahulu mempertimbangkan baik buruknya suatu gaya mengajar tersebut. Memilih gaya mengajar yang tepat tidaklah mudah. Dalam pelaksanaan dan penerapan gaya mengajar dalam pendidikan jasmani perlu di sesuaikan dengan kondisi dan situasi belajar mengajar nya karena pada prinsipnya tidak ada gaya mengajar yang paling baik untuk selamanya, setiap gaya mengajar memiliki kelebihan dan kekurangan tertentu pada gaya itu sendiri. Faktor - faktor ini harus di tekankan yang berkaitan dengan tujuan - tujuan tertentu dari pelajaran, kesiapan sisiwa untuk mengambil keputusan, peralatan yang tersedia, kesesuainya dengan pokok bahasan dan berbagai faktor lain. Walaupun guru sudah merasa nyaman dengan satu gaya mengajar namun bisa saja menimbulkan dampak yang tidak di harapkan, seperti kelelahan dan kejenuhan yang sering kali muncul sebagai akibat dari kurang tepatnya penerapan gaya mengajar tersebut. Banyak gaya mengajar yang dapat di gunakan dalam pembelajaran pendidikan jasmani di sekolah, salah satunya adalah gaya mengajar inklusi. Peneliti memilih gaya mengajar inklusi karena gaya mengajar inklusi dapat meningkatkan pola pikir siswa sehingga siswa menjadi kreatif dalam melaksanakan suatu tugas yang di berikan. Selain itu gaya mengajar inklusi merupakan suatu pemberian tugas dengan cara melihat kemampuan siswa secara peribadi terlebih dahulu sehingga siswa itu dapat melakukan tugas itu dengan baik tanpa harus di samakan secara merata dengan tingkat kesulitan yang sama. Hal ini di harapkan dapat meningkatkan hasil belajar passing bawah bola voli pada siswa. Pembelajaran passing bawah bola voli disekolah merupakan suatu proses belajar yang di lakukan dengan cara bimbingan, pemberian pengetahuan atau materi tentang passing bawah secara rinci dan terprogram kepada siswa. 
Pemberian materi juga harus memperhatikan siapa yang akan diberikan materi tersebut, karena tiap jenjang pendidikan memiliki karakter yang berbeda pada siswanya. Dengan melihat karakteristik siswa kelas XI SMK Swasta Yapim Biru-Biru, dimana siswa tersebut masih banyak yang malas dan bosan, maka seorang guru penjasorkes harus pandaipandai membuat inovasi atau variasi media pembelajaran yang dapat menarik minat siswa untuk dapat mengikuti pembelajaran dengan baik. Untuk bisa mengikuti pembelajaran dengan baik harus didasari rasa suka terlebih dahulu, karena apabila siswa sudah tidak suka terhadap media pembelajaran yang di berikan oleh guru maka siswa akan malas atau merasa bosan untuk mengikuti pembelajaran, yang pada akhirnya akan berpengaruh terhadap hasil belajar siswa tersebut. Berdasarkan pemahaman diatas, maka sebagai guru harus mampu menciptakan suatu metode baru,sehingga siswa tidak merasa bosan dan dapat mengikuti pembelajaran dengan baik. Begitu juga dalam pembelajaran passing bawah bola voli seorang guru harus bisa menciptakan media pembelajaran yang baru yang membuat siswa tertarik untuk mengikutinya. Salah satunya adalah dengan gaya mengajar Inklusi. Dengan menggunakan gaya mengajar Inklusi tersebut diharapkan siswa akan senang mengikuti pembelajaran yang juga pada akhirnya akan meningkatkan hasil belajar passing bawah bola voli. Gaya mengajar inklusi adalah suatu teknik pembelajaran yang di gunakan oleh guru, dengan cara menyajikan materi pembelajaran secara rinci dan menawarkan tingkat - tingkat kesulitan yang berbeda secara berurutan yang bertujuan agar siswa kreatif dan mendapatkan kemudahan dalam mempelajari suatu keterampilan gerak, siswa di beri kebebasan untuk memilih dan menentukan pada tingkat kesulitan mana ia memulai belajar suatu gerakan. Melalui gaya mengajar inklusi dalam mengajarkan teknik dasar passing bawah bola voli, siswa tidak hanya di tuntut untuk dapat melakukan gerakan namun siswa juga akan mengetahui sejauh mana tingkatan hasil yang telah di dapatnya dalam melakukan tugas yang di berikan. Dan dengan penerapan gaya mengajar inklusi, di harapkan dapat meningkatkan hasil belajar passing bawah dalam perminan bola voli pada siswa kelas XI SMK Swasta Yapim Biru-Biru.

\section{METODE PENELITIAN}

Penelitian yang digunakan dalam penelitian ini adalah Penelitian Tindakan Kelas (Classroom Action Research). PTK adalah penelitian yang dilakukan oleh guru, dalam kelasnya sendiri melalui refleksi diri, dengan tujuan untuk memperbaiki kinerjanya sebagai guru, sehingga hasil belajar siswa menjadi meningkat lebih baik dari sebelumnya. Alasan peneliti menggunakan PTK dalam penelitian ini adalah: 1) Membantu guru memperbaiki proses pembelajaran, 2) Membantu guru berkembang secara profesional, 3) Meningkatkan rasa percaya diri seorang guru., 4) Memungkinkan guru secara aktif mengembangkan pengetahuan dan keterampilan. Sesuai dengan jenis penelitian ini, yaitu Peneltian Tindakan Kelas (Classroom Action Research). Suyanto dalam Dewi (2015:10) mengatakan penelitian tindakan kelas adalah sebaga isuatu bentuk penelitian yang bersifat refleksi dengan melakukan tindakan-tindakan tertentu agar dapat memperbaiki dan meningkatkan praktekpraktek pembelajaran di kelas secara lebih professional.

\section{HASIL DAN PEMBAHASAN} Hasil 
Pembelajaran passing bawah bola voli sebelum menggunakan gaya mengajar inklusi di SMK Swasta Yapim Biru-Biru tahun ajaran 2020/2021 belum memenuhi kopetensi dasar permainan bola voli sesuai dengan kurikulum yang berlaku. Kemampuan siswa melakukan passing bawah serta hasil belajar yang di peroleh siswa masih sangat rendah. Siswa tidak serius mengikuti pelajaran karena pembelajaran yang di berikan guru tidak menarik. Setelah di terapkan penggunaan gaya mengajar inklusi pada pembelajaran passing bawah bola voli, sebagian siswa sudah dapat melakukan passing bawah bola voli dengan lebih baik. Terlihat dari data hasil siklus I pembelajaran passing bawah bola voli masih tergolong rendah dengan nilai rata-rata 78,21 dan presentase ketuntasan klasikal 58,82\%. beberapa kendala/kesulitan yang di temukan dalam pembelajaran siklus I, yaitu siswa kurang memahami tentang tugasyaitu tepatnya sikap tangan terutama dan sikap tubuh bagaimana bntuk tubuh yang benar dan juga kaki yang di tekuk dan juga masih ada beberapa siswa yang bingung dalam memutuskan mengulang tugas atau melanjutkan tugas selanjutnya. Untuk itu dalam pelaksanaan tindakan-tindakan d siklus II, guru memperjelas kembali tugas-tugas tersebut beserta tujuanya dan membimbing siswa dalam melakukan penafsiran terhadap tugas awalnya. Setelah pembelajaran siklus II berjalan dan hingga selesai, kemampuan siswa dalam melakukan passing bawah meningkat. Dari 17 orang siswa terdapat79 15 siswa telah mencapai nilai ketuntasan belajar ( tuntas ) dengan nilai rata-rata 85,40 dan presentase ketuntasan klasikal 88,24\%. Namun masih ada 2 siswa yang belum memperoleh ketuntasan belajar walaupun nilai yang di peroleh sudah meningkat di bandingkan dengan pembelajaran passing bawah bola voli sebelum di terapkanya gaya mengajar inklusi. Hal ini di karenakan siswa tersebut belum mampu melakukan seabagian dari indikator sikap awalan, pelakasanaan dan sikap akhir. Dari hasil observasi , kegiatan pembelajaran pada siklus I dan siklus II terjadi peningkatan dengan nilai rata-rata 78,21 dan 85,40. Di lihat dari hasil ini maka dapat di simpulkan bahwa melalui penerapan gaya mengajar inklusi dapat meningkatkan hasil belajar passing bawah bola voli pada siswa kelas XI SMK Swasta Yapim Biru-Biru tahun ajaran 2020/2021. Walaupun masih ada beberapa siswa yang belum mencapai ketuntasan namun secara klasikal jumlah siswa sudah mencapai ketuntasan belajar. Jadi penelitian ini tidak perlu dilakukan ke siklus berikutnya.

Salah satu faktor yang mendukung keberhasilan pembelajaran adalah penggunaan gaya mengajar pembelajaran yang sesuai dengan tujuan pelajaran yang ingin dicapai. Hal itu sangat berlaku juga untuk mata pelajaran Pendidikan jasmani seperti yang telah diuraikan sebelumnya bahwa kebanyakan siswa memiliki minat dan pehatian yang kurang dalam proses pembelajaran. Hasil tes siklus I ternyata nilai PKK yang diperoleh siswa 58,82\% dan hasil tes siklus II nilai PKK telah mencapai 88,24\%. Berdasarkan hal itu maka dapat ditarik kesimpulan bahwa pembelajaran melalui penerapan gaya mengajar Inklusi dapat Meningkatkan Hasil Belajar passing bawah bola voli Pada siswa kelas XI SMK Swasta Yapim Biru-Biru tahun ajaran 2020/2021.

Berdasarkan hasil tes passing bawah bola voli pada siklus II yang dilakukan kemampuan siswa telah meningkat menjadi lebih baik jika dibandingkan pada tes awal dan siklus I. Pada siklus II di peroleh yaitu 15 orang siswa $(88,24 \%)$ yang mencapai ketuntasan belajar dan yang belum mencapai ketuntasan belajar sebanyak 2 orang siswa $(11,76 \%)$. Jumlah keseluruhan yang diperoleh siswa pada saat melaksanakan sikap awalan adalah 163 dengan rata-rata siswa 8,15, jumlah keseluruhan siswa yang melaksanakan tahap Gerakan 
pelaksanaan adalah 144 dengan nilai rata-rata siswa 7,2, dan jumlah keseluruhan yang diperoleh siswa pada saat melaksanakan tahap gerakan lanjutan adalah 154 dengan nilai rata-rata 7,7. Jumlah skor keseluruhan siswa adalah 461 dengan nilai rata-rata 23,5, dan rata-rata kelasnya $85,37 \%$. Berikut tabel hasil belajar passing bawah bola voli siswa.

Pada siklus II diperoleh orang siswa (88,24\%) yang mencapai ketuntasan belajar dan yang belum mencapai ketuntasan belajar sebanyak 2 orang siswa $(11,76 \%)$. Dari paparan data ini menunjukkan adanya peningkatan hasil belajar passing bawah bola voli dari siklus I $58,82 \%$ menjadi $88,24 \%$ pada siklus II. Hasil belajar siklus II ini digunakan sebagai acuan dalam memberikan tindakan pembelajaran passing bawah bola voli bagi guru pendidikan jasmani di SMK Swasta Biru-Biru. Berdasarkan hasil observasi pada siklus II, proses belajar mengajar sudah berjalan lebih baik dibandingkan dengan pembelajaran siklus I. Jika pada siklus I ketuntasan klasikal siswa secara keseluruhan mencapai 58,82 \%,76 maka pada siklus II ketuntasan klasikal siswa keseluruhan meningkat menjadi 88,24 \%. Berdasarkan hasil observasi pada siklus II, peneliti masih perlu memberikan motivasi dan penguatan kepada siswa untuk mendukung terlaksananya pembelajaran yang lebih baik lagi. Pada pelaksanaan kegiatan, siswa telah memahami gerakan passing bawah bola voli dan telah mengetahui cara-cara memperbaiki kesalahan gerakan yang dilakukan di karenakan telah di berikan suatu masukan media gambar untuk mempermudah proses pembelajaran.

\section{KESIMPULAN}

Berdasarkan hasil penelitian dapat ditarik kesimpulan bahwa pembelajaran dengan menggunakan gaya inklusi dapat meningkatkan hasil belajar passing bawah bola voli pada siswa kelas XI SMK Swasta Yapim Biru-Biru tahun ajaran 2020/2021.

\section{DAFTAR PUSTAKA}

Adri, Sahabul. (2015). Upaya Meningkatkan Hasil Belajar Long Pasing Dalam Permainan Sepak Bola Dengan Menggunakan Gaya Mengajar Inklusi Pada Siswa Kelas XI Sma Negeri 4 Takengon Kabupaten Aceh Tengah. Jurnal Dosen STKIP Bina Bangsa Getsempena.2(2): 52-72.

Beutelstahl, Dieter. (2016). Belajar Bermain Bola Volley. Bandung: PIONIR JAYA

Chandra, Sodikin. (2010). Pendidikan Olahraga dan Kesehatan. Jakarta: Pusat Perbukuan Kementerian Pendidikan Nasional

Coker, Cherly A. (2004). Motor Learning and Control for Practitioners. New York: McGrawHill Companies

Dimyati dan Mudjiono. (2013). Belajar dan Pembelajaran. Jakarta: Rineka Cipta

Direktorat Jenderal Pembinaan Dasar dan Menengah. (2016). Panduan Penilaian Oleh Pendidik dan Satuan Pendidikan untuk Sekolah Menengah Pertama.Jakarta: Kemdikbud

Djamarah dan Zain. (2006). Strategi Belajar Mengajar. Jakarta: Rineka Cipta 
Hamalik, Oemar. (2013). Dasar-dasar Pengembangan Kurikulum. Bandung: PT. Remaja Rosdakarya

Hartanto, Agung Budi. (2014). Upaya peningkatan hasil belajar passing bawah voli melalui metode Kooperatif tipe stad pada siswa kelas v-asdn bangah gedangan sidoarjo.Jurnal

Sari, I. E. P. (2020). Efforts to Improve Learning Outcomes passing Down Volleyball Variations Through Learning and Modified Ball On Private Junior High School eighth grade students Perbaungan Satria Dharma School Year 2019/2020: Efforts to Improve Learning Outcomes passing Down Volleyball Variations Through Learning and Modified Ball On Private Junior High School eighth grade students Perbaungan Satria Dharma School Year 2019/2020. Journal of Midwifery and Nursing, 2(1), 173176.

Pendidikan Olahraga dan Kesehatan.2(3): 758-760.

Husdarta, J.S., Ely M. (2010). PendidikanJasmaniOlahragadanKesehatan. Jakarta: BSE 